http://ejournal.undip.ac.id/index.php/kapal

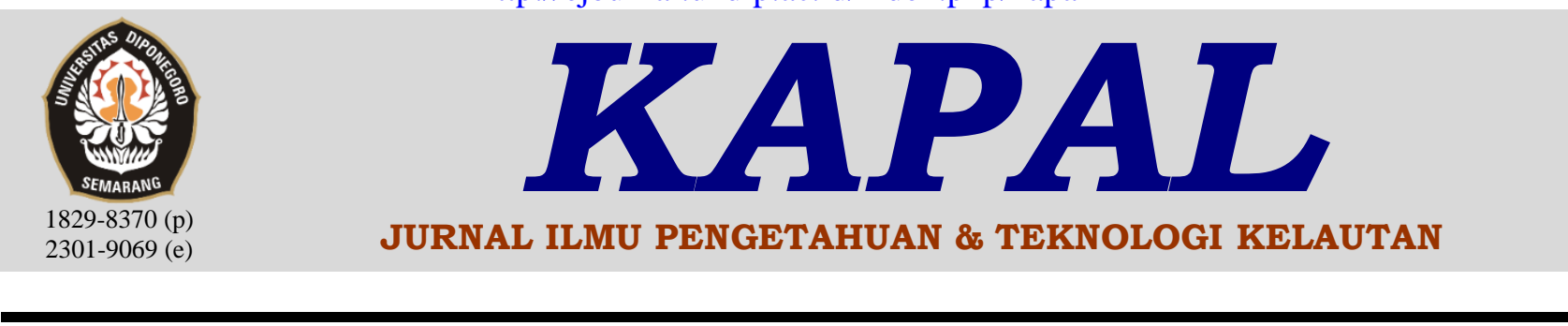

\title{
Studi Pemodelan Harga Kapal Tanker Bekas Dengan Metode Statistik
}

\author{
Heri Supomo ${ }^{\left.1)^{*}\right)}$, Imam Baihaqi ${ }^{1)}$ \\ ${ }^{1)}$ Departemen Teknik Perkapalan, Fakultas Teknologi Kelautan, \\ Institut Teknologi Sepuluh Nopember (ITS) - Surabaya 60111
}

diajukan pada : 19/03/19 direvisi pada $: 30 / 04 / 19 \quad$ diterima pada $: 07 / 05 / 19$

\begin{abstract}
Abstrak
Salah satu alasan pemodal membeli kapal tanker bekas adalah karena lamanya waktu pembangunan dan tingginya biaya investasi untuk membangun sebuah kapal baru. Namun demikian terkait dengan harga kapal tanker bekas, saat ini masih belum ada metode yang tepat untuk memprediksi nilainya. Multi-faktor seperti: tahun pembuatan, kapasitas kapal, negara asal pembuat, dan operasional kapal menjadikan proses memprediksi harga kapal ini menjadi lebih kompleks dibandingkan single-faktor. Kompleksitas tersebut membuat penentuan harga kapal tanker bekas pula menjadi berbeda-beda antar penilai. Estimasi harga kapal bekas yang kurang tepat dapat merugikan perusahaan jika harga beli lebih mahal dari nilai kapal bekas sesungguhnya. Tujuan dari paper ini adalah membuat pemodelan statistik untuk memprediksi harga kapal tanker bekas agar mendekati harga semestinya. Pemodelan dibuat secara simultan dengan mempertimbangkan faktor kualitatif meliputi umur kapal dan ukuran DWT dan faktor kuantitatif dimana mengacu pada galangan pembuat, klas dan negara asal pembuat kapal. Data kapal yang terkumpul, yang diperoleh dari data pusat broker kapal internasional secara online, kemudian dianalisa secara statistik dengan melakukan regresi secara multikolinearitas. Data-data ini kemudian diuji secara statistik antara lain yaitu: uji serentak, uji individu, uji asumsi normalitas, uji asumsi heteroscedasticity, dan penentuan koefisien determinasi. Korelasi kuadratik didapatkan antara umur dengan harga kapal, sedangkan umur dengan DWT berhubungan secara logaritmik. Kedua korelasi ini kemudian disimultankan dan didapatkan model secara statistik berdasarkan lima kelompok negara asal pembuat (Eropa (beberapa negara), Jepang, Korea, China, dan Asia Tenggara (beberapa negara termasuk Indonesia)). Jika kelompok Asia Tenggara dijadikan acuan, maka pada kelas Minibulker kelompok Eropa dan Jepang jauh lebih mahal sekitar 40\% disusul Korea 21,0\% dan China hanya 0,5\% lebih mahal. Pada kelas Handysize, selisih harga untuk kelompok Eropa adalah 13,7\% lebih mahal, disusul Korea sebesar 7,2\%; sebaliknya, selisih harga di Jepang dan China lebih murah 4,9\% dan 5,9\%.
\end{abstract}

Copyright (C) 2019, KAPAL, 1829-8370 (p), 2301-9069(e)

Kata Kunci : Harga kapal bekas, ukuran DWT, umur kapal, kelompok negara asal pembuat

\section{PENDAHULAN}

Dampak lahirnya program Tol Laut yang meliputi penyelenggaraan kewajiban pelayanan publik untuk angkutan barang di laut adalah bangkitnya industri kapal nasional. Pada perkembangannya sampai saat ini, jumlah armada kapal niaga wajib ditingkatkan tidak terkecuali kapal tanker sebagai moda distribusi energi

\footnotetext{
*) Penulis Korespondensi :

Email : hsupomo1964@gmail.com
}

nasional [1]; [2]. Untuk memenuhi jumlah armada kapal tanker nasional, fenomena yang banyak terjadi di lapangan adalah pembelian kapal tanker bekas. Hal ini dikarenakan adanya beberapa fakta di lapangan bahwa untuk membangun kapal baru dibutuhkan waktu yang relatif cukup lama jika dibandingkan dengan membeli kapal bekas. Sebagai contoh untuk membuat kapal jenis tanker dengan kapasitas 16500 DWT dibutuhkan waktu pembangunan sekitar 2 tahun, sedangkan proses 
pembelian kapal tanker bekas hanya memerlukan beberapa bulan saja [3]; [4]; [5].

Kondisi ini mendorong munculnya beberapa bisnis ship broker tanker bekas. Tugas dari shipbroker salah satunya adalah penjualan dan pembelian kapal bekas (secondhand ship sales and purchase). Lembaga ini berfungsi menjembatani penjual kapal (ship owner) dan pembeli kapal (ship buyer). Saat ini ada beberapa perusahaan terkenal yang berkecimpung dalam bisnis ship broker. Perusahaan tersebut di antaranya: Clarksons, SSY (Simpson, Spence, \& Young), Braemer, Seascope, Charles Weber, Gibsons, Galbraiths dan J.E. Hyde [6]; [7].

Penaksiran harga kapal bekas sangat berbeda dengan kapal baru. Estimasi harga kapal baru lebih mudah dan hanya merupakan penjumlahan biaya jasa desain, pembangunan kapal, pajak dan margin keuntungan yang diambil oleh galangan pembangun. Sedangkan harga kapal bekas merupakan sebuah nilai (value) yang sangat relatif dan tergantung kondisi kapal bekas. Nilai tersebut ditaksir dengan memperhatikan beberapa faktor yang mempengaruhi di antaranya: (a) faktor kuantitatif meliputi: umur kapal dan kapasitas kapal; (b) faktor kualitatif meliputi: reputasi galangan pembuat, bendera kapal, dan klasifikasi, dan (c) faktor spesifik meliputi: kondisi historis kapal tersebut, dan riwayat operasi [4]; [8].

Saat ini penilaian harga kapal tanker bekas dilakukan oleh orang-orang yang telah berpengalaman di bidang tersebut. Kebanyakan penaksir harga kapal bekas merupakan orang yang bekerja untuk perusahaan ship broker, sehingga nilai taksiran harga antara satu penilai dan lainnya kadangkala sangat berbeda. Kesalahan dalam estimasi harga kapal dapat menyebabkan kerugian besar bagi perusahaan jika harga beli kapal bekas lebih mahal dari nilai kapal bekas semestinya.

Mengingat pentingnya untuk memecahkan permasalahan perbedaan perkiraan harga kapal tanker bekas, maka perlu didapatkan metode yang reliable untuk meminimalkan perbedaan tersebut, dimana salah satunya adalah pemodelan secara statistik. Untuk memodelkan harga kapal tanker bekas secara statistik, beberapa dasar teori dan literatur terkait diperlukan dan dijadikan pertimbangan. Beberapa referensi yang melatarbelakangi penulisan ini meliputi beberapa aspek yang perlu dicermati untuk diakomodasi. Dengan demikian permodelan yang dihasilkan akan mendekati nilai semestinya. Hal-hal yang perlu diperhatikan meliputi:

a. Fakta Penilaian Harga Kapal Bekas

Penilaian kapal sangat penting untuk dilakukan sebagai bahan pertimbangan penentuan harga kapal bekas. Penilaian secara menyeluruh akan meningkatkan akurasi penilaian dalam memberikan informasi kepada pihak yang berkepentingan. Akan tetapi, hal yang sering terjadi adalah diabaikannya penilaian kapal secara menyeluruh, dan perhatian hanya diberikan pada aspek tertentu saja. Badan kapal bekas pada umumnya dijadikan acuan pokok penilaian, sedangkan beberapa aspek lain penentu nilai kapal seharusnya perlu diperhitungkan secara seksama. Beberapa aspek yang dimaksud meliputi: kondisi mesin utama dan mesin bantu, dan kondisi keseluruhan sistem dalam kapal. Namun demikian fakta di lapangan, kebanyakan penaksir harga kapal bekas hanya menaksir berdasarkan dokumen yang tertulis di atas kertas [9].

b. Faktor Pertimbangan Pembelian Kapal Bekas Kapal-kapal yang didesain dan dibangun untuk daerah peruntukan negara-negara di Eropa tidak mudah dioperasikan begitu saja untuk perairan di Indonesia. Meskipun memiliki bentuk lambung kapal yang sama, pengoperasian pada perairan yang berbeda (apalagi beda benua) sebaiknya mempertimbangkan faktor-faktor penting lainnya. Secara lebih ekstrim, meskipun desain yang dibuat sama namun dibangun oleh galangan kapal yang berbeda, maka kapal tersebut tidak akan pernah disebut sebagai "Sister Vessel" tetapi akan disebut "Similar Vessel". Kapal yang dibangun indentik tapi untuk peruntukan daerah operasional yang berbeda akan menyebabkan beberapa perubahan desain dan instalasi permesinan serta perlengkapan yang berbeda. Daerah operasi kapal dapat saja dipaksakan dengan berbagai alasan, namun hal ini akan menimbulkan konsekuensi jika dianalisa menurut cost-benefit-analysis. Perbedaan mendasar dimungkinkan akan timbul seperti biaya operasional kapal menjadi lebih besar walaupun bentuk dan spesifikasi teknis kapal itu sama [10]; [11].

Oleh karena itu pembelian kapal bekas seharusnya mempertimbangkan faktor-faktor yang sangat berpengaruh dalam penilaian harga. Faktor ini merupakan variabel yang digunakan dalam studi permodelan ini [12]:

- Suku cadang permesinan dan ketersedian suku cadang baik di daerah area operasional lokal dan regional bahkan dukungan internasional. 
- Pelayanan jasa perusahaan spesialis peralatan dan permesinan (Service company for specialist equipment and machinery).

- Ketersediaan galangan kapal baik untuk normal docking ataupun emergency docking.

- Kualitas bahan bakar dan minyak pelumas serta pengaruhnya terhadap kinerja mesin induk dan bantu.

- Dengan berkembangnya teknologi monitoring and control, maka teknologi kontrol otomatis perlu dikaji untuk antisipasi masa depan.

- Akses dan kemudahan untuk melakukan bongkar-pasang peralatan dan permesinan

- Crane and repair pier facility untuk perbaikan terapung.

- Logistic support untuk mendatangkan spare parts and service Specialist Company.

\section{METODE}

Urutan studi ini diawali dengan identifikasi variabel pemodelan statistik yang akan dianalisa. Selanjutnya langkah penyelesaian model harga kapal tanker bekas ini dapat dijelaskan sebagai berikut:

\subsection{Indentifikasi Variabel}

Variabel yang akan digunakan untuk mengestimasi harga kapal tanker bekas adalah umur dan DWT (Dead Weight). Umumnya semakin tua umur sebuah kapal, harganya akan turun, dan sebaliknya semakin besar DWT nya maka semakin tinggi harganya. Namun demikian, pembelian kapal tanker bekas sangat dipengaruhi pula oleh pertimbangan faktor kualitatif: kelompok negara/negara asal kapal bekas dibangun (dalam hal ini galangan dari negaranegara yang memiliki reputasi baik dalam membangun kapal dan ketat tidaknya pengawasan biro klasifikasi), dan kondisi sertifikat klas kapal masih berlaku atau tidak. Dengan demikian harga kapal tanker bekas dapat diekspresikan ke dalam bentuk model fungsi (umur, DWT, dan negara asal pembangun).

\subsection{Pengumpulan Data}

Data ukuran kapal tanker bekas yang tersedia sangat bervariasi dan terbagi menjadi beberapa kelas ukuran. Ukuran kapal tanker terbagi menjadi beberapa kelas sesuai ukuran utama. Kelas yang dimaksud meliputi: ULCC, VLCC, Aframax, Panamax, Suezmax, Capesize, Malaccamax, Handysize dan Minibulker. Pengelompokan ini didasarkan pada bisa tidaknya melewati kanal dan selat yang ada dunia. Terusan dan selat yang dimaksud adalah: terusan Suez, kanal Panama dan selat Malaka. Hal ini sangat berpengaruh terhadap kapasitas dan daerah / radius pelayaran kapal tanker tersebut. Klasifikasi kapal tanker berdasarkan ukurannya dapat dijelaskan pada Tabel 1.

Tabel 1. Klasifikasi ukuran kapal tanker. [13]

\begin{tabular}{cc}
\hline Tankers - class & Cargo (DWT) \\
\hline Minibulker & $<10,000$ \\
Handysize & $10,000-50,000$ \\
Panamax & $65,000-80,000$ \\
Aframax & Max 79,999 \\
Suezmax & $120,000-200,000$ \\
Capesize & $100,000-180,000$ \\
VLCC & $200,000-299,999$ \\
ULCC & $300,000-500,000$ \\
\hline
\end{tabular}

Sehubungan dengan kondisi di Indonesia, data ukuran kapal tanker di titik beratkan pada kelas Minibulker dan Handysize. Tanker Handysize dipilih sebagai objek penulisan karena pertimbangan aksesibilitas ke semua terminal pelabuhan yang ada di dunia termasuk pelabuhan yang ada di Indonesia. Sedangkan kelas Minibulker sangat cocok untuk perairan pantai dan sangat sesuai jika dipakai di perairan Indonesia.

Pengambilan data kapal tanker bekas didasarkan pada umur ekonomis kapal tanker yaitu berkisar antara 5-25 tahun yang didapatkan melalui data online sampai tahun 2017. Data kapal yang dikumpulkan merupakan kapal single classification atau dual-classification dengan sertifikat masih berlaku [3]. Biro klasifikasi yang dimaksud antara lain: Bureau Veritas (BVFrance), China Classification Society (CCSChina), Det Norske Veritas Classification (DnVNorway), Germanischer Lloyd (GL-Germany), Korean Register of Shipping (KRS-Korea), Lloyd's Register of Shipping (LR-UK), Nippon Kaiji Kyokai (NK-Japan) [14]

Galangan asal pembuat kapal dikelompokkan berdasarkan kelompok regional negara/negara sebagai berikut: 1). Kelompok Eropa (Belgia, Kroasia, Denmark, Finlandia, Prancis, Jerman, Yunani, Italia, Belanda, Norwegia, Polandia, Portugal, Rumania, Slovakia, Spanyol, Swiss, Turki, Inggris Raya (UK)), 2). Jepang, 3). Korea, 4). China, dan 5). Asia Tenggara (Filipina, Singapura, Malaysia, Vietnam dan Indonesia). Pengelompokan ini didasarkan pada nilai harga kapal tanker bekas rata-rata yang hampir sama untuk setiap kelompok negara/negara dengan berbagai ukuran; dan kelima kelompok negara ini 
memiliki perbedaan rata-rata harga yang signifikan untuk dibandingkan.

Di samping itu beberapa pedoman yang digunakan dalam pengumpulan data kapal pada paper ini adalah berdasarkan teori statistik menurut [15]. Berdasarkan pedoman tersebut maka data-data harga dioleh secara lebih rinci dengan langkah sebagai berikut:

a) Harga kapal bekas didata dengan unit harga yang sama. Dalam hal ini, data harga kapal tanker bekas yang digunakan adalah dalam satuan US\$, jika data harga dalam mata uang lain maka dikonversi menjadi US\$.

b) Organisasi / lembaga ataupun perorangan yang mempublikasikan data kapal tanker bekas harus diperhatikan tingkat kepercayaannya. Data-data harga kapal bekas diperoleh dari penyedia data kapal bekas yang sudah lama dan terpercaya, misalnya: CW. Kellock \& Co Ltd, salah satu pialang internasional untuk penjualan dan pembelian semua jenis kapal laut, dan beroperasi dari kota London, didirikan pada tahun 1820 dan diakui secara internasional.

c) Pengumpulan informasi secara rinci terkait data kapal tanker bekas yang telah dikumpulkan melalui transaksi data hasil penjualan kapal secara online. Pengumpulan data rinci ini misalkan kondisi kapal secara fisik, kondisi permesinan dan outfitting serta daerah pelayarannya. Hal ini dilakukan untuk memudahkan proses analisa data.

Berdasarkan teori statistik, untuk melakukan studi pemodelan, maka diperlukan beberapa pertimbangan faktor yang disesuaikan dengan variabel kapal tanker bekas, di antaranya:

\section{- Faktor Kuantitatif}

Faktor kuantitatif jika diselaraskan dengan spesifikasi kapal meliputi: tonage, dimensi, kapasitas, kecepatan, fasilitas cargo handling/kapasitas pompa, dan pemenuhan dengan peraturan terbaru (double-hull tanker). Selain itu juga wajib mempertimbangkan umur kapal dan jadwal special survey berikutnya dilakukan. Faktor ini digunakan untuk membandingan secara kuantitatif langsung terhadap kapal lain. Berdasarkan metode penilaian faktor kuantitatif, umumnya dapat disimpulkan bahwa: kapal tanker ukuran lebih besar dan lebih muda umurnya diasumsikan bernilai lebih mahal. Namun demikian jika faktor ini berdiri sendiri, nilai yang diperoleh belum dapat mencerminkan nilai pasar sesungguhnya [16].

\section{- Faktor Kualitatif}

Beberapa faktor kualitatif yang mempengaruhi harga sebuah kapal tanker antara lain: reputasi galangan kapal, bendera kapal, dan biro klasifikasi yang digunakan. Hal tersebut memiliki efek yang signifikan terhadap harga kapal bekas. Hal ini sangat berdampak terhadap kepercayaan pembeli sehingga berpengaruh pada nilai kapal tanker bekas. Variabel kualitatif akan menentukan kecenderungan untuk membeli kapal bekas. Dengan demikian penilai membuat tabulasi data di antaranya: kelompok negara/ negara pembangun, operator, life time, dan nilai pasar kapal bekas [17].

- Faktor Khusus

Beberapa faktor khusus yang mempengaruhi harga sebuah kapal tanker bekas di antaranya adalah: kondisi visual kapal, sejarah pemakaian, sejarah perawatan, rute pelayaran kapal, dan data kecelakaan. Faktor spesifik ini akan dapat dipakai sebagai bahan pertimbangan untuk menentukan apakah kapal bekas tersebut bernilai tinggi atau rendah berdasarkan faktor khusus tersebut. [18].

\subsection{Analisa Regresi}

Analisa regresi merupakan sebuah analisa untuk mencari pengaruh suatu variabel terhadap variabel yang lain. Hasil analisa regresi berupa persamaan yang memuat fungsi variabel respon (dependen) dengan menggunakan satu atau lebih variabel prediktor (independen). Dalam model regresi dengan variabel bebas lebih dari satu maka antar variabel bebas tersebut tidak dibolehkan saling berkorelasi. Asumsi ini dinamakan asumsi multikolinearitas. Bila asumsi tersebut tidak memenuhi maka model yang ada tidak dapat digunakan untuk menaksir harga sebuah kapal bekas. Pengujian ini dilakukan dengan melihat nilai VIF (Variance Inflation Factor) dimana bila nilai VIF lebih dari 10 maka dikatakan terjadi multikolinearitas.

Analisa ini bertujuan untuk mendapatkan hubungan antara respon harga kapal tanker bekas terhadap prediktornya (DWT dan umur) pada kelompok negara pembuat kapal sebagaimana dijelaskan sebelumnya. Bentuk umum model regresi serentak seperti pada Persamaan 1.

$$
\ln (y)=\beta_{0}+\beta_{1} \ln \left(x_{1}\right)+\beta_{2}\left(x_{2}\right)^{2}+\varepsilon
$$

dimana y adalah harga kapal (US\$), $x_{1}$ adalah umur (tahun), $x_{2}$ adalah DWT (ton) dan $\beta_{0}, \beta_{1}, \beta_{2}, \varepsilon$ adalah konstanta. 
Hasil regresi berdasarkan pemodelan statistik terhadap harga kapal tanker bekas, seperti pada persamaan (1), masih perlu dilakukan beberapa uji lagi, yaitu:

\section{a. Uji Serentak}

Koefesian regresi diuji secara serentak dengan menggunakan ANOVA. Untuk mengetahui apakah koefisien yang ada dalam model secara serentak (bersama) signifikan atau tidak terhadap model dengan $\alpha=0,05$ digunakan uji F [19].

Hipotesisnya adalah :

$H_{0}: \beta_{0}=\beta_{1}=\beta_{2}=0$ (model tidak signifikan)

$H_{l}$ : paling tidak ada satu dari $\beta \neq 0$ (model signifikan)

Di mana $\mathrm{i}=0,1,2$ adalah contoh uji salah satu permodelan. Kesimpulan yang diambil adalah $\mathrm{H}_{0}$ ditolak jika $P_{\text {-value }}<\alpha$ atau $F_{\text {hit }}>F_{\alpha(p, n-p-1) \text {. }}$ Nilai $P_{\text {-value }}$ didapat pada tabel ANOVA.

$\begin{array}{ll}H_{o} & : \text { Hipotesis Nol } \\ H_{1} & : \text { Hipotesis Alternatif } \\ P_{\text {-value }} & : \text { Besarnya peluang } \\ \alpha & : \text { Batas kesalahan maksimal } \\ F_{\text {hit }} & : \text { F hasil perhitungan } \\ F_{\alpha(p, n-p-1)} & : \text { F pada tabel ANOVA }\end{array}$

b. Uji Individu

Uji individu digunakan untuk menguji apakah koefesien regresi $\beta_{0}, \beta_{1}$ dan $\beta_{2}$ secara individu mempunyai pengaruh yang signifikan atau tidak bagi variabel y pada model regresi. Pengujian dilakukan dengan uji $\mathrm{T}$ atau $\mathrm{P}$-value dengan taraf nyata $\alpha=0,05$.

$H_{0}: \beta_{1}=0$ (koefisien regresi tidak signifikan)

$H_{1}: \beta_{1} \neq 0$ (koefisien regresi signifikan),

Dimana $\mathrm{i}=0,1,2$, dst.

Hasil uji akan menolak $H_{0}$ (hipotesis awal) jika $P_{\text {-value }}<\alpha$. Jika memakai uji T dengan derajat bebas n-p-1 maka $H_{0}$ akan ditolak jika $T_{h i t}>$ $T_{\text {tabel }}=T_{(1-\alpha / 2, n-p-1)}[20]$

$\begin{array}{ll}P_{\text {-value }} & : \text { Besarnya peluang } \\ \alpha & : \text { Batas kesalahan maksimal } \\ T_{\text {hit }} & : \text { T hasil perhitungan } \\ T_{\text {tabel }}=T_{(1-\alpha / 2, n-p-1)} & : \text { nilai T pada tabel }\end{array}$

c. Uji Asumsi Normalitas

Uji Normalitas dimaksudkan untuk mengetahui apakah suatu data yang diteliti berdistribusi normal atau tidak. Uji Kolmogorov Smirnov merupakan suatu tes Goodness of fit, artinya tingkat kesesuaian antara distribusi serangkaian harga sampel (data observasi) dengan suatu distribusi teoritis. Uji ini mencakup perhitungan distribusi frekuensi kumulatif yang akan terjadi di bawah distribusi teoritisnya, serta membandingkan distribusi frekuensi itu dengan distribusi komulatif hasil data observasi. Pengujian kenormalan residual untuk yaitu:

$$
\begin{aligned}
& \mathrm{H}_{0} \text { : residual berdistribusi normal } \\
& \mathrm{H}_{1} \text { : residual tidak berdistribusi normal }
\end{aligned}
$$

Statistik uji Kolmogorov Smirnov adalah :

$$
\begin{gathered}
\mathrm{D}_{\text {hit }}=\sup _{x}\left|F_{o}(x)-S_{n}(x)\right| \\
\text { dimana } \mathrm{S}_{\mathrm{n}}\left(\mathrm{x}_{\mathrm{i}}\right)=\mathrm{i} / \mathrm{n}
\end{gathered}
$$

$F_{0}(x)$ merupakan suatu fungsi Cumulative Distribution Frequency (CDF) yang sepenuhnya ditentukan, yaitu CDF teoritis dibawah $H_{0}$. Sedangkan $S_{n}(x)$ merupakan CDF yang diobservasi dari suatu sampel random dengan $\mathrm{N}$ observasi. Pengambilan keputusan $H_{0}$ ditolak pada taraf nyata $\alpha$ jika $D_{\text {hit }}>D_{\text {tabel }}$ atau $\mathrm{P}$-value $<\alpha$.

\section{d. Uji Asumsi Heteroscedasticity}

Uji heteroscedasticity bertujuan untuk menguji apakah dalam model regresi terjadi ketidaksamaan ragam dari residual satu data dengan yang lain. Gejala varians yang tidak sama ini disebut heteroscedasticity, sedangkan adanya gejala varians residual yang sama dari satu pengamatan ke pengamatan yang lain disebut dengan homoscedasticity. Cara untuk menguji heteroscedasticity ini adalah dengan melihat penyebaran dari varians residual melalui plot antara $e_{i}$ (residual) dan $\hat{y}_{i}$ (variabel bebas) atau dengan uji Glejser yaitu dengan meregresikan nilai absolut residual analisis regresi dengan nilai variabel bebas regresi. Apabila $P_{\text {-value }}$ koefisien regresi antara nilai absolut residual dengan nilai variabel bebas regresi signifikan yaitu lebih kecil dari maka persamaan regresi tersebut mengandung heteroscedasticity sedangkan sebaliknya disebut homoscedasticity.

e. Koefisien Determinasi

Koefisien Determinasi $\left(\mathrm{R}^{2}\right)$ yang menunjukkan bagian dari varian total juga ikut dihitung. Jika nilai $\mathrm{R}^{2}$ semakin mendekati nilai 1 , maka pemodelan regresi dapat dikatakan hampir mendekati populasi harga kapal bekas sesuai dengan variabel-variabelnya dan dengan ini jumlah sampel data telah memenuhi [21].

\section{HASIL DAN PEMBAHASAN}

Rekapitulasi jumlah kapal yang dijadikan sampel pada masing-masing kelompok negara dapat disimak pada Tabel 2, dengan data ukuran kapal mulai dari 1000 DWT sampai dengan $\leq$ 
50.000 DWT dan rentang harga terendah dan tertinggi. Detail dari data kapal masing-masing berdasarkan ukuran DWT, umur (rentang 5-25 tahun), dan harga kapal tidak dicantumkan, namun sejumlah data kapal yang terkumpul merupakan data dengan distribusi normal. Berdasarkan detail data dari masing-masing sejumlah kapal, dilakukan analisa korelasi variabel baik individu maupun serentak dimana didapatkan bentuk korelasi linier, kuadratik dan logaritmik.

Tabel 2. Rekapitulasi Data Sampel Kapal Tanker Bekas [14]

\begin{tabular}{llccccc}
\hline \multirow{2}{*}{ No } & \multirow{2}{*}{ Negara Asal } & \multirow{2}{*}{$\begin{array}{c}\text { Jumlah kapal } \\
(\text { Buah) }\end{array}$} & \multicolumn{2}{c}{ DWT (ton) } & \multicolumn{2}{c}{ Harga (USD x 1000) } \\
\cline { 4 - 6 } & & 198 & 1.168 & 47.288 & 600 & 52.000 \\
\hline 1 & Grup Eropa & 277 & 1.200 & 48.700 & 1.050 & 56.000 \\
2 & Jepang & 203 & 1.000 & 49.700 & 580 & 59.000 \\
3 & Korea & 124 & 2.000 & 46.000 & 920 & 50.000 \\
4 & China & 152 & 1.107 & 44.646 & 650 & 49.000 \\
5 & Grup Asia Tenggara & & & & & \\
& (Termasuk Indonesia) & & &
\end{tabular}

\subsection{Analisis Korelasi variabel}

Sebelum menganalisa antara variabel respons harga kapal tanker bekas dengan dua prediktornya (umur dan DWT) secara langsung, terlebih dahulu dilakukan analisa respon terhadap masing-masing prediktornya untuk mengetahui bentuk korelasinya. Sebelum prosedur perhitungan koefisien regresi serentak, langkah ini perlu dilakukan agar diperoleh model yang lebih akurat [22].

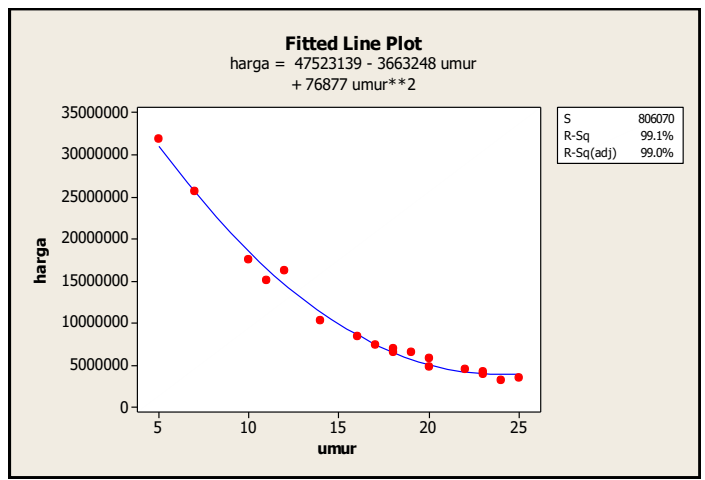

Gambar 2. Hubungan antara umur dan harga kelas Minibulker kelompok negara Jepang

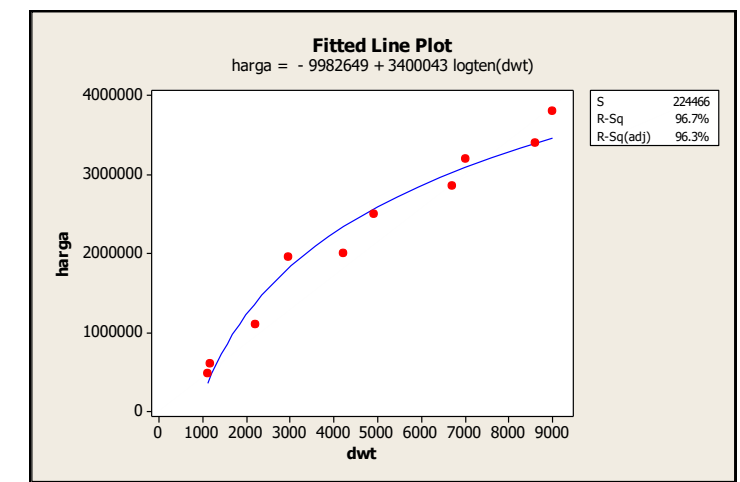

Gambar 3. Hubungan antara DWT dengan harga kelas Minibulker kelompok negara Jepang
Gambar 2 dan Gambar 3 merupakan salah satu grafik hasil analisa korelasi variabel (umur dan DWT dengan harga) pada sampel data kapal yang tersebar di kelompok negara Jepang pada kelas Minibulker. Seperti telah dijelaskan bahwa data kapal yang digunakan adalah sejumlah unit kapal dengan ukuran dan harga yang dikelompokkan pada masing-masing kelompok negara, dimana data ini terdistribusi normal.

Berdasarkan grafik pada Gambar 2 didapatkan hubungan antara respon umur dengan harga memiliki hubungan faktor determinan $\mathrm{R}^{2}=$ $0.99 \%$. $\mathrm{F}_{\alpha(1,16)}=4,494$ dan $\mathrm{P}_{\text {-value }}<\alpha$, hal ini menunjukan koefisien regresi berpengaruh terhadap model. Asumsi residual normalitas yang memiliki $\mathrm{P}_{\text {-value }}>0,15$. Dengan demikian dapat disimpulkan bahwa hubungan antara umur dengan harga kapal tanker bekas mempunyai hubungan kuadratik. Dengan persyaratan analisa statistik yang sama seperti halnya hubungan kuadratik, maka hubungan yang terjadi antara DWT dengan harga adalah logaritmik.

\subsection{Hasil Regresi Permodelan}

Setelah mengetahui hubungan respon dengan masing-masing prediktornya, maka ketiga variabel tersebut ditransformasikan menjadi $y, x_{I}$ dan $x_{2}$ dalam grafik regresi 3-D pada masingmasing kelompok negara asal pembuat. Gambar 4 merupakan salah satu contoh grafik regresi 3-D pada kapal kelas Minibulker pada kelompok negara Jepang. 


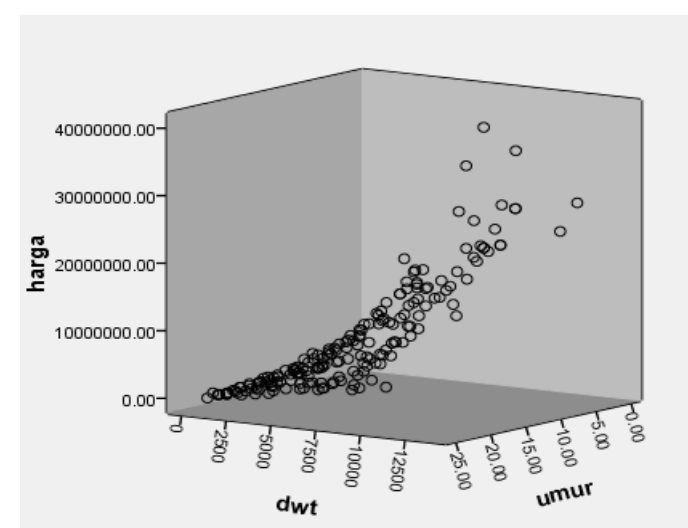

Gambar 4. Plot regresi 3-D antara DWT, umur dan harga kapal produksi Jepang pada kelas Minibulker

Selanjutnya grafik pada Gambar 4 dianalisa dengan menggunakan bantuan Software Minitab sehingga diperoleh persamaan model matematis sesuai Persamaan 3 untuk kelompok kapal kelas Minibulker sebagai berikut:

$$
y=7.62-0.0033\left(x_{1}\right)^{2}+1.04 \ln \left(x_{2}\right)
$$

Dimana:

$$
\begin{aligned}
y & =\text { harga (USD); } \\
\mathrm{x}_{1} & =\text { umur kapal (tahun); } \\
\mathrm{x}_{2} & =\text { DWT (ton) }
\end{aligned}
$$

Untuk membuktikan bahwa Persamaan 3 ini signifikan dan sensitif, maka perlu dilakukan beberapa uji. Uji yang pertama adalah uji individu (uji T), dimana model persamaan untuk kelompok negara Jepang pada kelas Mini Bulker memiliki nilai $\mathrm{P}_{\text {-value }}$ yang kurang dari 0,05 dan $\mathrm{T}_{\text {tabel }}=$ 1,973. Sehingga disimpulkan bahwa pada persamaan tersebut koefisien $\beta_{0}, \beta_{1}$ dan $\beta_{2}$ sangat signifikan berpengaruh pada luaran persamaan model matematis.

Uji berikutnya adalah uji $\mathrm{F}$ (uji serentak) dimana didapatkan $\mathrm{F}_{\text {hit }}=2,314$ yang lebih dari $\mathrm{F}_{\alpha}$ $(2,183)=3,892$. Dengan demikian dapat disimpulkan
$H_{0}$ ditolak, yaitu menolak hipotesis awal dan menerima hipotesis alternatifnya atau dengan kata lain koefisien regresi secara serentak berpengaruh signifikan pada permodelan untuk kelompok negara Jepang kelas Minibulker.

Uji yang ketiga adalah uji Normalitas residual $\mathrm{P}_{\text {-value }}>0,05(5 \%)$ dimana pada permodelan persamaan untuk kelompok negara ini diperoleh nilai $\mathrm{P}_{\text {-value }}>0,150$ atau residual berdistribusi normal dan dapat diterima dan tidak terjadi heterodeskesidas. Pada uji koefisien determinasi, pemodelan untuk kelompok ini memiliki koefisien determinansi $96.2 \%$ yang hampir mendekati nilai $100 \%$, sehingga memenuhi.

Langkah regresi dan beberapa uji dilakukan untuk semua data terkait kapal tanker bekas ukuran Minibulker dan Handysize dengan beberapa variasi kelompok negara asal pembangun kapal bekas untuk didapatkan pemodelan matematis lainnya sebagaimana dijelaskan pada hasil pemodelan.

\subsection{Hasil Permodelan}

Berdasarkan hasil regresi pada semua data kapal tanker bekas berdasarkan kelompok negara asal pembuat, maka didapatkan model matematis untuk kelas Minibulker dan Handysize sebagaimana tercantum pada Tabel 3. Hasil pemodelan ini dapat menentukan prediksi harga kapal tanker bekas berdasarkan kelompok negaranya pada batasan ukuran sesuai pada data sampel kapal. Berdasarkan pemodelan, kemudian didapatkan selisih perbedaan harga untuk masingmasing kelompok negara berdasarkan ukuran kapal dan umur kapal. Dengan pemodelan matematis sesuai dengan Tabel 3, maka calon

\begin{tabular}{|c|c|}
\hline Negara Asal & Model Persamaan \\
\hline Japan*M & $\operatorname{Ln}(\mathrm{y})=7.62-0.0033\left(\mathrm{x}_{1}\right)^{2}+1.04 \ln \left(\mathrm{x}_{2}\right)$ \\
\hline Japan*H & $\operatorname{Ln}(\mathrm{y})=14.1-0.00277\left(\mathrm{x}_{1}\right)^{2}+0.317 \ln \left(\mathrm{x}_{2}\right)$ \\
\hline \#Eropa*M & $\operatorname{Ln}(y)=8.09-0.00266\left(x_{1}\right)^{2}+0.956 \ln \left(x_{2}\right)$ \\
\hline \#Eropa*H & $\operatorname{Ln}(\mathrm{y})=14.6-0.00274\left(\mathrm{x}_{1}\right)^{2}+0.285 \ln \left(\mathrm{x}_{2}\right)$ \\
\hline Korea*M & $\operatorname{Ln}(\mathrm{y})=7.69-0.00271\left(\mathrm{x}_{1}\right)^{2}+0.988 \ln \left(\mathrm{x}_{2}\right)$ \\
\hline Korea*H & $\operatorname{Ln}(y)=12.1-0.00314\left(x_{1}\right)^{2}+0.530 \ln \left(x_{2}\right)$ \\
\hline AsTeng*M & $\operatorname{Ln}(y)=6.68-0.00201\left(x_{1}\right)^{2}+1.051 \ln \left(x_{2}\right)$ \\
\hline AsTeng*H & $\operatorname{Ln}(\mathrm{y})=13.4-0.00256\left(\mathrm{x}_{1}\right)^{2}+0.389 \ln \left(\mathrm{x}_{2}\right)$ \\
\hline China*M & $\operatorname{Ln}(\mathrm{y})=5.61-0.0022\left(\mathrm{x}_{1}\right)^{2}+1.18 \ln \left(\mathrm{x}_{2}\right)$ \\
\hline China*H & $\operatorname{Ln}(\mathrm{y})=14.1-0.00298\left(\mathrm{x}_{1}\right)^{2}+0.318 \ln \left(\mathrm{x}_{2}\right)$ \\
\hline
\end{tabular}
pembeli akan dengan mudah memprediksi harga dasar dari kapal tanker bekas.

Tabel 3. Hasil pemodelan kapal tanker bekas (Minibulker dan Handysize) 
Keterangan :

\#Eropa : Perwakilan beberapa negara-negara

AsTeng: beberapa negara-negara di Asia

Tenggara termasuk Indonesia

M : Minibulker

$\mathrm{H} \quad$ : Handysizes

$\mathrm{x}_{1} \quad$ : Umur kapal tanker (tahun)

$\mathrm{x}_{2} \quad$ : DWT kapal tanker (ton)

y : Harga kapal (USD)

\subsection{Pembahasan Perbedaan Harga Kapal}

Berdasarkan hasil pemodelan seperti tertera pada Tabel 3, maka didapatkan perbandingan harga kapal tanker bekas pada kelas Minibulker dan Handysize pada masing-masing kelompok negara. Kemudian hasil perbedaan ini dibahas dan dianalisa berdasarkan faktor-faktor kualitatif dan kuantitatif sebagaimana dijelaskan sebelumnya.

Secara sekilas terlihat bahwa pada kelompok Minibulker (Gambar 4) kelompok Eropa dan Jepang menduduki 2 kelompok negara dengan harga kapal tanker bekas tertinggi dan relatif sama dengan nilai sekitar US\$ 5 juta, sebaliknya kelompok China dan kelompok negara di Asia Tenggara (termasuk Indonesia), dengan harga kapal bekas relatif sama pada nilai sedikit di atas US\$ 3,5 juta, menduduki 2 kelompok terendah dari kelima kelompok. Harga kapal tanker bekas buatan kelompok Korea berada di tengah-tengah antara dua kelompok tertinggi dan terendah dengan nilai sekitar US\$ 4,3 juta.

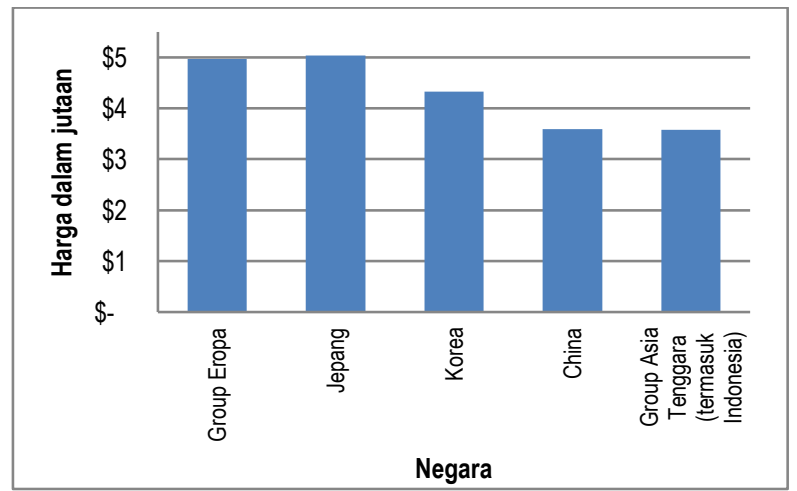

Gambar 4. Perbandingan harga kapal tanker bekas kelas Minibulker

Jika dibuat prosentase, maka jika kelompok negara Asia Tenggara (termasuk Indonesia) dijadikan sebagai acuan untuk harga kapal tanker bekas pada kelas Minibulker, maka Group Eropa dan Jepang jauh lebih mahal sebesar 39,0\% dan $40,6 \%$ berturut-turut, disusul Korea dengan perbedaan signifikan sebesar $21.0 \%$ lebih besar. Harga kapal bekas pada kelompok China relatif sama dengan kelompok negara Asia Tenggara (termasuk Indonesia), dengan selisih perbedaan sangat kecil sebesar $0.5 \%$.

Secara kontras, trend perbedaan harga pada kelas Minibulker sangat berbeda dengan trend pada kelas Handysize (Gambar 5). Jepang dimana merupakan kelompok dengan harga kapal tanker bekas tertinggi pada kelas Minibulker, pada kelas Handysize menjadi kelompok negara dengan harga kapal bekas paling rendah bersama China dengan nilai sedikit di bawah US\$ 25 juta. Kelompok Asia Tenggara (termasuk Indonesia), pada kelas ukuran ini, memiliki harga sedikit lebih tinggi dibandingkan Jepang dan China pada nilai sekitar US\$ 26,0 juta, namun masih di bawah Korea yang mencapai nilai US\$ 27,8 juta. Kelompok Eropa tetap menduduki nilai paling tinggi dibandingkan ke empat kelompok lainnya dengan nilai sekitar USD 29,5 juta.

Sebagaimana pada kelas Minibulker, jika kelompok Asia Tenggara (termasuk Indonesia) dijadikan sebagai benchmark, maka prosentase selisih harga kapal tanker bekas pada kelas Handysize untuk kelompok Eropa adalah 13,7\% disusul Korea sebesar 7,2\% lebih mahal. Sebaliknya, Jepang dan China lebih murah 4,9\% dan $5,9 \%$ berturut-turut pada kelas ini.

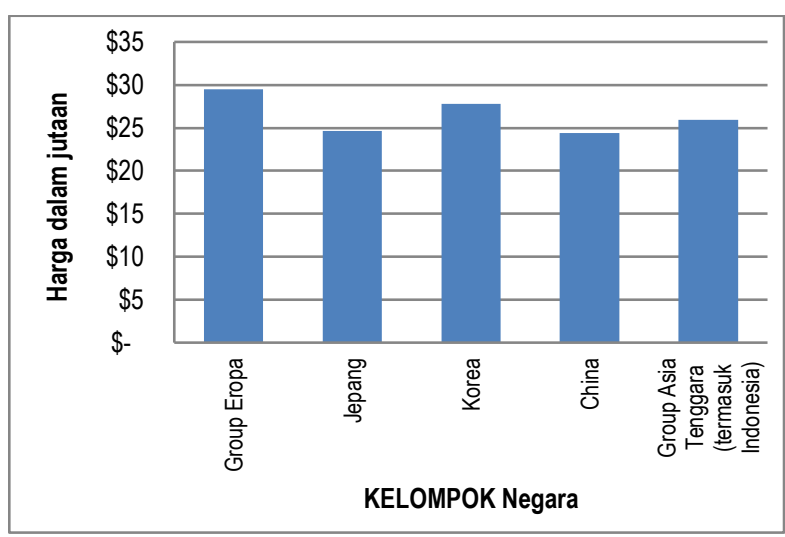

Gambar 5. Perbandingan harga kapal antar negara pada kelas Handysize

Harga kapal tanker bekas ditentukan oleh beberapa faktor kondisi kapal seperti umur, DWT, kondisi kapal saat ini, historis pemakaian, permintaan dan penawaran. Faktor-faktor tersebut menjadi pengaruh yang membuat harga kapal tanker bekas diberbagai kelompok negara berbeda. Umur kapal berhubungan dengan harga kapal secara logaritmik dimana semakin tua umur kapal harganya semakin rendah dan berhubungan secara logaritmik; sedangkan DWT kapal berhubungan secara kuadratik dimana semakin besar ukuran DWT maka harga kapal semakin mahal dengan hubungan secara kuadratik. Rekam pemakaian, nilai permintaan dan penawaran juga menjadi pengaruh besar terhadap harga kapal 
bekas. Sejarah perbaikan dan perawatan kapal serta jenis dan frekuensi kerusakan yang terjadi menjadi pertimbangan tertentu dalam harga, sedangkan hukum ekonomi (supply and demand) juga berlaku pada jual-beli kapal bekas.

Selain itu faktor kualitatif seperti reputasi kelompok negara asal galangan pembuat dan klasifikasi juga dapat mempengaruhi harga kapal tanker bekas, dimana ada anggapan bahwa kapal buatan kelompok Eropa, Jepang, dan Korea masih lebih baik dan lebih tahan lama daripada buatan kelompok negara di Asia Tenggara (termasuk Indonesia) dan China. Hal tersebut dapat mempengaruhi faktor kuantitatif, seperti jumlah permintaan kapal bekas pada ketiga kelompok negara tersebut menjadi tinggi dan harga pasaran menjadi tinggi pula. Sedangkan harga kapal tanker bekas dari kelompok Asia Tenggara (termasuk Indonesia) dan China dianggap cenderung lebih murah karena kondisi sebaliknya.

Pada kelas Minibulker, harga kapal tanker bekas dari kelompok Asia Tenggara (termasuk Indonesia) dan China cenderung lebih murah karena kondisi kapal sub-standar (kapal yang dilihat secara fisik, operasional, dan aktivitas ABK tidak memenuhi standar dasar dari kelaiklautan dan perlindungan terhadap lingkungan laut). Kapal ini juga disebut sebagai kapal dengan pengawasan Port State Control yang rendah. Contoh kondisi kapal sub-standard antara lain: tutup palka yang bocor, ruang muat yang kotor dan berkarat, crane yang rusak, dan efisiensi mesin yang sudah turun drastis (tidak mampu mendorong kapal secara efisien). Secara operasional, kapal-kapal ini sudah tidak memperhatikan keselamatan, polusi, dan kondisi kerja. Kapal-kapal kelompok ini juga dianggap setara dengan kapal non-klas (kapal yang pernah diklaskan atau klas namun masa berlakunya habis) pada tingkat harganya.

Sebagai ilustrasi, Gambar 5 menunjukkan grafik perbandingan harga kapal bekas pada kelas Minibulker antara kapal klas dan kapal non-klas. Secara sekilas terlihat bahwa semua kapal nonklas relatif lebih murah dibandingkan kapal kelas dengan selisih harga antara $\pm 10 \%$ sampai dengan $\pm 20 \%$ pada 5 kelompok DWT yang berbeda (A, B, C, D, E). Kelompok B (DWT 3200an), A (DWT 2500an), dan E (DWT 8200an) merupakan 3 kelompok dengan selisih harga tertinggi. Selisih harga masing-masing kapal adalah berturut-turut $19,29 \%, 18,5 \%$, dan $17,97 \%$ lebih murah dibandingkan kapal klas. Sedangkan kelompok C (DWT 5000an) dan kelompok D (DWT 4500an) memiliki selisih harga berturut-turut $12,24 \%$ dan 10,25\% lebih murah dibandingkan kapal klas.

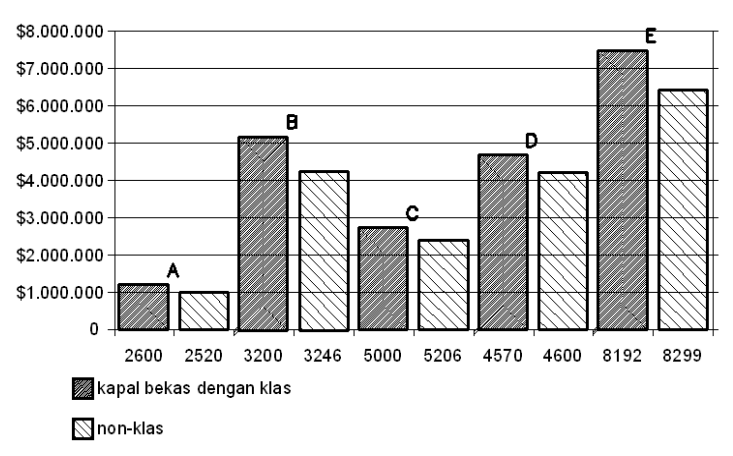

Gambar 5. Perbandingan kapal bekas Minibulker antara klas dan non-klas pada 5 kelompok ukuran DWT.

Hasil sebaliknya terjadi pada kelas Handysize, dimana kapal-kapal ini cenderung digunakan untuk mendistribusikan muatan ke tempat yang lebih jauh antar negara dibandingkan kelas Minibulker. Kapal harus memenuhi peraturan standar internasional yang berlaku, sehingga hal ini berdampak pada selisih harga kapal bekas pada 5 kelompok negara yang relatif tidak terlalu besar jika dibandingkan selisih pada kelas Minibulker. Terlihat pada analisa sebelumnya bahwa selisih harga pada kapal bekas Minibulker berada pada nilai sekitar $40 \%$ antara nilai harga terendah dengan tertinggi. Sedangkan pada kelas Handsize, selisih terbesar hanya sekitar $19,7 \%$, yaitu antara China dengan Kelompok Eropa, dimana nilai ini sekitar kurang dari setengah dari selisih pada kelas Minibulker.

\section{KESIMPULAN}

Untuk memperkirakan harga kapal tanker bekas dapat digunakan pemodelan dengan pendekatan metode statistik mencakup variabel: umur, DWT dan parameter kelompok negara asal galangan pembuat kapal. Terdapat perbedaan harga kapal bekas antara kelompok negara asal pembuat galangan yang satu dengan lainnya. Perbedaan harga terbesar terdapat pada kelas Minibulker dimana mencapai sekitar 40\%, sedangkan pada kelas Handysize selisih terbesar pada harga kapal hanya sekitar separo dari kelas Minibulker.

Pada kelas Minibulker, jika kelompok Asia Tenggara (termasuk Indonesia) dijadikan acuan, maka Grup Eropa dan Jepang jauh lebih mahal sebesar sekitar $40 \%$ disusul Korea 21,0\% dan China $0.5 \%$. Sedangkan pada kelas Handysize dengan benchmark kelompok negara yang sama, maka Grup Eropa tetap berada pada selisih tertinggi sebesar $13,7 \%$ diikuti kelompok Korea $7,2 \%$. Sebaliknya, selisih sekitar 5\% pada harga kapal tanker bekas untuk kelas Handysize di Jepang dan China lebih murah dibandingkan 
dengan kelompok Asia Tenggara (termasuk Indonesia).

\section{UCAPAN TERIMA KASIH}

Terima kasih saya sampaikan kepada seluruh kolega di Departemen Teknik Perkapalan, FTK, ITS yang telah memberikan semangat untuk menyelesaikan artikel ini. Penghargaan sebesarbesarnya juga saya sampaikan kepada keluarga saya yang dengan tulus ikhlas telah mendorong penyelesaian penulisan ini.

\section{DAFTAR PUSTAKA}

[1] Perpres 106, 'Perspres no:106 Tahun 2015', Jakarta: Sekretariat Kepresidenan, 2015, pp. 1-4.

[2] Permenhub no: 4, PermenHub No_4_Tahun_2016.pdf. Jakarta: Kementrian Perhubungan Republik Indonesia, 2016.

[3] N. Wijnolst and T. Wergeland, Shipping Innovation. 2009.

[4] M. Kalouptsidi, 'Time to build and fluctuations in bulk shipping', Am. Econ. Rev., 2014.

[5] E. R. Gultom, 'Merefungsi Pengangkutan Laut Indonesia Melalui Tol Laut Untuk Pembangunan Ekonomi Indonesia Timur', Develop, 2017.

[6] William Henry, 'Newman, William Henry, (3 Feb. 1865-13 April 1947), Ship-Broker; Senior Partner of W. H. Newman and Son since 1927', in Who Was Who, 2017.

[7] Sir John, 'Burke, Sir John, (died 14 March 1922), DL; JP; ship-broker', in Who Was Who, 2018.

[8] R. Greenwood and S. G. Hanson, 'Waves in ship prices and investment', $Q$. J. Econ., 2015.

[9] A. S. Denisi and K. R. Murphy, 'Performance appraisal and performance management: 100 years of progress?', $J$. Appl. Psychol., 2017.

[10] M. Roe, 'Maritime economics', J. Transp. Geogr., 2002.

[11] International Chamber of Shipping, 'Shipping and World Trade', Overview of the International Shipping Industry Shipping, 2017. .

[12] R. Adland and S. Koekebakker, 'Ship valuation using cross-sectional sales data: A multivariate non-parametric approach', Marit. Econ. Logist., 2007.

[13] Maritime Connector, 'Ship Sizes', Maritime Connector, 2019. [Online].
Available: http://maritimeconnector.com/wiki/ship-sizes/. [Accessed: 19-Apr-2019].

[14] Marine Digital, 'Ship Business Center', 2018. [Online]. Available: https://www.marinedigital.com/en/. [Accessed: 15-Mar-2018].

[15] M. Kuncoro, 'Metode Kuantitatif: Teori dan Aplikasi untuk Bisnis dan Ekonomi', Yogyakarta: AMP YKPN, 2001.

[16] W. Shi, Z. Yang, and K. X. Li, 'The impact of crude oil price on the tanker market', Marit. Policy Manag., 2013.

[17] D. V. Lyridis, P. Zacharioudakis, P. Mitrou, and A. Mylonas, 'Forecasting tanker market using artificial neural networks', Marit. Econ. Logist., 2004.

[18] W. Abouarghoub, I. Biefang-Frisancho Mariscal, and P. Howells, 'Dynamic Earnings within Tanker Markets: An Investigation of Exogenous and Endogenous Structure Breaks', Am. Int. J. Contemp. Res., 2012.

[19] J. D. Schwager and M. Etzkorn, 'Introduction to Regression Analysis', in $A$ Complete Guide to the Futures Market, 2017.

[20] V. K. Mutalik et al., 'Quantitative estimation of activity and quality for collections of functional genetic elements', Nat. Methods, 2013.

[21] J. W. Gooch, 'Coefficient of Determination', in Encyclopedic Dictionary of Polymers, 2011.

[22] G. M. Fitzmaurice, 'Regression', Diagnostic Histopathology. 2016. 